\title{
Degree of Implementation of the Language Provisions in Primary and Secondary Schools in Southwestern Nigeria
}

\author{
B. B.Adeyemi ${ }^{1, *} \&$ Y. A. Ajibade ${ }^{2}$ \\ ${ }^{1}$ General and Entrepreneurial Studies Unit, Faculty of Science, Ondo State University of Science and Technology \\ (OSUSTECH), Okitipupa, Nigeria \\ ${ }^{2}$ Department of Special Education and Curriculum Studies, Faculty of Education, Obafemi Awolowo University, \\ Ile-Ife, Nigeria \\ *Corresponding author: General and Entrepreneurial Studies Unit, Faculty of Science, Ondo State University of \\ Science and Technology (OSUSTECH), Okitipupa, Nigeria. E-mail: adeyemibeatrice163@yahoo.com
}

Received: February 21, 2014

Accepted: April 4, 2014

Online Published: August 13, 2014

doi:10.5430/wje.v4n4p92

URL: http://dx.doi.org/10.5430/wje.v4n4p92

\begin{abstract}
The study determined the degree of implementation of the language provisions in the National Policy on Education (NPE)in Nigerian primary and secondary schools. The study adopted the survey design. The sample size consisted of 1,620 pupils in primary schools, 1,620 students in secondary schools totalling 3,240 and 300 English Language teachers. The 3,240 students and pupils were selected using stratified random sampling technique while the 300 English Language teachers were selected using convenience sampling techniques from three senatorial districts in each of the six states (Ekiti, Ogun, Osun, Oyo, On do and Lagos) in Southwestern Nigeria. The language teachers were made up of 109 males and 191 females. Two instruments titled "Degree of Implementation of Language Provisions Questionnaire" (DIPQ) and "Degree of Implementation of Language Provisions Observation Checklist"(DIPOC)were designed by the researchers for the study. One research question was asked and answered while five research hypotheses were tested at the 0.05 level of significance. Data were analysed using simple percentages, t-test and ANOVA statistics. The results showed that the degree of implementation of the language provisions was low as attested to by $94 \%$ of teachers and confirmed by the researchers who found that only $10.3 \%$ of teachers used the medium of instruction stipulated in the NPE. Results further showed no significant differences in the responses of primary and secondary, male and female, rural and urban, and public and private school teachers on the degree of implementation of the language provisions in the NPE $(t=0.749, p>0.05, t=0.424, p>0.05, t=0.902$, $\mathrm{p}>0.05, \mathrm{t}=0.741, \mathrm{p}>0.05$ respectively). Furthermore, there was no significant difference in teachers' experience and their responses on the degree of implementation of language provisions in the NPE ( $F=0.031, p>0.05)$. It was recommended that appropriate avenues should be provided for teachers' awareness of the language provisions as specified in the NPE and adequate strategies should be put in place for their implementation. Proper monitoring would be required to ensure compliance.
\end{abstract}

Keywords: implementation; language provisions; primary and secondary schools

\section{Introduction}

Language occupies a prominent place in any nation. People in every society have a way of interacting with one another via language. The Federal Government, in recognition of the pivotal role of language, makes provisions for it in the National Policy on Education (NPE).The NPE (FGN, 2004) reflects government's intention of using the Mother Tongue (MT) as a medium of instruction in the early stage of a child's school life, with transition to English as a medium of instruction in the upper primary classes. The following language provisions are made in the Policy:

The medium of instruction in the primary school shall be the language of the environment for the first three years. During this period, English shall be taught as a subject.

From the fourth year, English shall progressively be used as a medium of instruction and the language of immediate environment (p. 9) 
Furthermore, provisions are made for the secondary school, which comprises both the junior and senior school, that English is the medium of instruction while the language of the environment and one major Nigerian language other than that of the environment are to be taught(NPE, p. 12). It can be deduced from the language provisions that the government confers major language status on three languages which are somewhat regarded as regional languages: Hausa in the North, Yoruba in the West and Igbo in the East (Ogunsiji, 2001). Researchers see some merits in these provisions. For example, Fafunwa (2005) does not see the use of indigenous languages as a barrier; rather, he is of the opinion that depriving the indigenous speaker of his language for education is like removing his soul. Education in the mother tongue removes all the inhibitions that beset the use of a foreign language. The mother tongue makes it possible for the learner to give free reins to his thoughts and express same in creative language thus paving the way for meaningful education. In the same vein, Oladipo (2003) also opines that some children particularly in the rural areas only come into contact with the English Language when they begin primary school.

As laudable as these provisions are, researchers such as Ajibade (2001), Babalola (2002) and Bamgbose (2003) opine that the extent of implementation of the language provisions as stipulated in the NPE is quite low. The level of students' proficiency in terms of the use of language skills and the degree of the mastery of these skills for communication and education are equally low. Ikiddeh (2011) expresses his views on the non-implementation of the language provisions in schools on the basis that the pre-primary education of children at ages 3 to 5 years or thereabouts has been left in the hands of private individuals and organisations. As a result, from the first day of the pupils' resumption in school, the indigenous languages are prohibited and they are taught to communicate in English. Spillane, Reiser and Reimer (2002) assert that in government schools, the mother tongue is seldom used because the teachers are not aware of the objectives of the language provisions. Thus, they swing to English as a medium of instruction. Emenanjo (2004) advocates the need for well-informed language policies and implementation strategies.

Policy and implementation are closely related as policy includes intended effects, that is, policy envisages implementation. Hence, a policy is not real until the intended changes have taken place (Pressman and Wildavsky, 1974). Implementation entails a process of interaction between the setting of goals and actions geared to achieving them. Studying the process of implementation, therefore, includes the setting of goals towards which implementation is directed. In implementing the objectives of the language provisions, appropriate supervision is an ultimate necessity. According to Tuoyo (1999), supervision deals with constant and continuous monitoring of the performance of school staff, noting merits and demerits and using befitting and amicable techniques to ameliorate the flaws while still improving on the merits, thereby increasing the standard of schools and achieving educational goals.

The language provisions considered as the National Language Policy in Nigeria are the result of extensive consultations that began way back in 1995, with the appointment of the Language Task Group (LANGTAG). The implementation plan outlines strategies for implementing the language policy, proposing key implementation structures, and mechanisms for accelerating the development and promotion of African languages (Nancy, 2010). The government is conscious of the challenges involved in the efficient management of linguistic diversity. It is for this reason that the implementation plan proposes an approach that is both flexible and progressive. Therefore, the collaborative partners at national, provincial and local government levels are expected to play a critical role in ensuring the successful implementation of the language policy.

Implementation in language policy consists of the measures, plans, strategies, mechanisms that provide the authoritative backbone (including financial rewards and resources) to achieve the goals of the language policy, and the motivation to use the language by the people affected. The success of language policies in general, is achieved through careful language planning and implementation. The often unpredictable and dynamic multilingual context presents a challenge to policy and planning whereby changes in language practice tend to influence the outcomes of language policy and vice versa (Barkhuizen, 2002). If the context is not carefully observed, it could lead to language planning being futile or difficult to manage in accommodating language diversity, which is essential in ensuring that democratic rights and structures are in place and are fulfilled by the state (Tollefson, 1991).

The centrality of language to the teaching-learning process, the importance of Nigerian languages to the protection, preservation and promotion of Nigeria and the necessity of learning a major language for purposes of promoting national unity and integration have constitutional backing in the 1989 constitution of the Federal Republic of Nigeria and educational justification in the NPE. However, in educational matters as in other areas, Nigeria is one nation that is very high and rich in policies but very low and deficient in implementation.

Various scholars (Ajibade, 1991; Emenanjo, 1996; Phillipson, 2003; and Owu-Ewie, 2006) point out that no matter how benign or enlightened a language policy may be in its form, it needs to be implemented carefully or it will certainly fail to achieve the outcome its planners intended, and will thus just remain an empty rhetoric. 
Implementation requires vigilant monitoring to see that all the important issues are being executed. Aside this, carefully constructed policies also involve evaluation, that is, a way to check periodically to see if the plan isn't going as scheduled and what measures can be taken to rectify the shortcomings. Many plans fizzle at the implementation stage because there is no coordination or accountability for outcomes. Good intentions, broad consensus, and intricate plans are insufficient without sustained leadership and periodic formal assessments of progress. The best policy will amount to nothing unless it is implemented. Follow-up is the weakest and most neglected part of the policy making process, the stage during which good ideas die due to lack of attention. Without proper follow-up, conditions can drift back to the former state, soon after implementation.

Since language is a communicative tool in the lives of individuals and communities, it is imperative that strategies to redress past language inequalities be put in place. The implementation plan for language provisions of a policy provides details regarding the structured mechanisms required to operate the policy, and the financial/budgetary implications for national and provincial development. Such a policy is clear on the scope for implementation. All government structures (national, provincial and local government) are bound by the provisions of the policy, as are any institutions exercising a public power. According to Bamgbose (1994), the implementation process is guided by the aims and objectives set out in the policy. The following are key focus areas for implementation:

a) The development of the indigenous languages, including the establishment of infrastructures and the development of products such as dictionaries and grammars;

b) The reinforcing of government responsibility to ensure that the benefits of service delivery are distributed equally by providing equitable access to services for all citizens irrespective of language in order to enhance their participation and voice in government matters;

c) The management of language to ensure the functional use of all the official languages and to promote the public image of the government;

d) The encouragement of language learning, specifically tailored to the needs of the public service, to improve public servants' efficiency and productivity in the work place and make the benefits of multilingualism visible;

e) The encouragement of vibrant discourse on multilingualism, language role-players and stakeholders.

The implementation of the policy is expected to be characterized by the following key tenets:

a) The implementation of the language policy will be phased progressively over a reasonable period.

b) The process of implementation will occur within clearly set and manageable targets.

c) Capacity will be built incrementally for meaningful and effective implementation.

d) Successful implementation will require a change in culture of use of official languages in government structures to ensure that the indigenous languages are actively used in a range of contexts.

e) Effective management of resources will be necessary with regard to the increased demand for translation and editing, especially in the African languages.

f) The progress of policy implementation will be evaluated regularly in close collaboration with the Pan South African Language Board (PanSALB). Detailed reports on such reviews will be published.

g) Research in language use will be commissioned when necessary to inform policy and implementation decisions.

In the Federal Government's efforts to implement the language provisions in the NPE, a seminar was organized by the Language Development Centre of the NERDC at the Gateway International Hotel, Ota in 1991. According to Emenanjo (1998), the specific objective of the seminar was a comprehensive review of the implementation procedures for realizing the objectives of the language provisions of the NPE. The Ota Seminar dealt specifically with, among others:

i. General problems of implementation of the language provisions of the NPE;

ii. $\quad$ Programme for the training of teachers for Nigerian language provisions of the NPE;

iii. $\quad$ Curricula and syllabuses for Nigerian languages as L1 and L2, English and Foreign languages;

iv. Review of curricula, syllabuses and pedagogy of English and Foreign languages in the educational system;

v. Research requirements for the implementation of the language provision of the NPE; etc

Some of the recommendations made at the Ota Seminar on language policy and curricula objectives are as follows:

i. Government should continue with its policy of multilingualism. 
ii. Government should review and restate in a clearer form the language provisions of the NPE.

iii. Government should provide active encouragement to the implementation of the MT/LIC medium of instruction policy at the primary school level.

iv. Appropriate curricula agencies should review and/or design more functional curricula for (Nigerian) languages.

v. Government should involve linguists and language specialists in all policy matters involving language in this country.

vi. The language provisions of the NPE and their implementation should be constantly monitored and evaluated.

As positive as these recommendations are, not much has been translated into practice which unfortunately has an adverse effect on the implementation of the language provisions in the NPE.As Bamigbose (2003, p.17) observes 'the failure of many policy plans is due to the absence of adequate implementation procedures'. A comprehensive policy formulation must be backed by a strong will on the part of policy makers and planning agents to ensure implementation to the letter. The cost may look prohibitive, as Essien (2003) argues, but that should not dissuade any government that has both the capacity and the will. The present study is borne out of the fact that there does not appear to be precise observable indices of implementation of policy provisions or its lack. Since the 2004 NPE was introduced into schools, the performance of students in English, and by extension in other subjects, has not improved particularly in Southwestern Nigeria. This may be a necessary pointer to the continuous state of lack of implementation. Consequently, to come up with empirical data on the present state of implementation or non-implementation of language provisions in Southwestern Nigeria, one research question was asked and answered and five hypotheses were formulated and tested.

\section{Research Question}

What is the degree of implementation of the language provisions in primary and secondary schools in Southwestern Nigeria?

\section{Research Hypotheses}

1. There is no significant difference in responses of primary and secondary school teachers in Southwestern Nigeria on the degree of implementation of the language provisions in the NPE.

2. There is no significant difference in responses of male and female teachers in Southwestern Nigeria on the degree of implementation of the language provisions in the NPE.

3. There is no significant difference in responses of rural and urban school teachers in Southwestern Nigerian on the degree of implementation of the language provisions in the NPE.

4. There is no significant difference in responses of public and private school teachers in Southwestern Nigeria on the degree of implementation of the language provisions in the NPE.

5. There is no significant difference in teachers' experience and their responses on the degree of implementation of the language provisions in the NPE.

\section{Methodology}

The research adopted the survey design. The population for the study comprised all the primary school pupils, secondary school students and English language teachers in Southwestern Nigeria. The sample size consisted of 1,620 pupils, 1,620 students and 300 English language teachers from three senatorial districts in each of the six states (Ekiti, Ogun, Osun, Oyo, Ondo and Lagos) in Southwestern Nigeria. In each senatorial district, six streams of classes, primaries 4, 5, 6, JSS II, JSS III and SSS1 were selected using stratified random sampling. From each of the primary and secondary schools, 90 students were selected also using stratified random sampling technique with class level as stratum giving a total of 3,240 students while the 300 English language teachers were selected using convenience sampling technique. The language teachers were made up of 109 males and 191 females. Two instruments titled "Degree of Implementation of Language Provisions Questionnaire" (DIPQ) and "Degree of Implementation of Language Provisions Observation Checklist" (DIPOC) were designed by the researchers to collect data. The DIPOCelicited information from the teachers which allowed the researchers to make inferences on the degree of their implementation of the language provisions in the NPE. Items on the instrument were generated from literature 
on the development and implementation of educational policies and programmes (Markee 1997, Ehindero, 2012).The questionnaire has three sections. Section A consists of items on teachers' demographic data such as: age, sex, school location, school type, class, occupation, work experience, qualification and local government area. Section B consists of 30 items on statements relating to the degree of implementation of the language provisions. Respondents were expected to choose from each of the items on a five-point adapted Likert-type scale ranging from Not at all to Great Extent. The instrument was scored 0 for Not at all, 1 for Undecided, 2 for Little Extent, 3 for Some Extent, and 4 for Great Extent.

The observation checklist was used during observation of teachers and their pupils/students in the class in order to ascertain whether teachers actually implemented the language provisions in the course of teaching as stipulated in the NPE. The checklist has two sections. Section A consists of teachers' demographic data such as school location, school type, qualification, age, sex, and work experience. Section B contains13 statements with options ranging from Not at all, Partially to Fully, which were to be ticked by researchers as teachers were being observed as they taught in their classes. The items in the checklist were scored as follows: 0 for Not at all, 1 for Partially and 2 for Fully.

The instruments were validated using CronbachAlpha and the alpha values obtained yielded 0.79 and 0.78 respectively. Data collected were analysed using simple percentage, t-test and ANOVA statistics.

\section{Results}

\subsection{Research Question}

What is the degree of implementation of the language provisions in primary and secondary schools in Southwestern Nigeria?

In answering this question, a checklist was provided to observe English language teachers in the class to ascertain whether the appropriate medium of instruction was used. Also, secondary data collected from responses obtained from teachers in private and public primary and secondary schools in Southwestern Nigeria were analyzed using percentages. The results are presented in Tables 1 and 2.

Table 1. Degree of Implementation of the Language Provisions in Primary and Secondary Schools in Southwestern Nigeria by Teachers as Observed while Teaching in the Classroom

\begin{tabular}{lllll}
\hline $\begin{array}{l}\text { Degree of } \\
\text { implementation }\end{array}$ & Frequency & Percent & Valid percent & $\begin{array}{l}\text { Cumulative } \\
\text { percent }\end{array}$ \\
\hline Low & 199 & 66.4 & 66.4 & $67.2 \%$ \\
Moderate & 70 & 23.3 & 23.3 & $23.4 \%$ \\
High & 31 & 10.3 & 10.3 & $10.4 \%$ \\
Total & 300 & 100.0 & 100.0 & \\
\hline
\end{tabular}

Table 1 displays primary data on the degree to which the English Language teachers implemented the language provisions during observation as they taught in their classes. Instead of using only English in the upper primary and secondary schools, $66.4 \%$ of teachers used the mother tongue together with English as the medium of instruction. The stipulated medium for instruction was implemented by only $10.3 \%$ which indicates a very low degree of implementation of the language provisions and confirms the teachers' responses as shown in Table 2.

Table 2. Degree of Implementation of the Language Provisions in Primary and Secondary Schools in Southwestern Nigeria as indicated by Teachers

\begin{tabular}{lllll}
\hline \multirow{2}{*}{$\begin{array}{l}\text { Degree of } \\
\text { Implementation }\end{array}$} & Frequency & Percent & Valid percent & Cumulative percent \\
\hline Low & 282 & 94 & 94 & 94 \\
Moderate & 10 & 3.3 & 3.3 & 97.3 \\
High & 8 & 2.66 & 2.66 & 100.0 \\
Total & 300 & 100.0 & 100.0 & \\
\hline
\end{tabular}

Table 2 shows the degree to which language provisions are implemented as perceived by teachers themselves. Of the 300 teachers, 282 (94\%)were of the view that the implementation of the language provisions is low. A look at teachers' responses on the degree of implementation vis-à-vis some pertinent variables reveals a level of consensus as revealed in the results below. 


\subsection{Research Hypotheses}

5.2.1 There is no significant difference in responses of primary and secondary school teachers in Southwestern Nigeria on the degree of implementation of the language provisions in the NPE.

Table 3. t-test Showing Difference in Responses of Primary and Secondary School Teachers

\begin{tabular}{lllllllll}
\hline Variable & Scategory & $\mathbf{N}$ & $\mathbf{Z}$ & sd & df & $\mathbf{t}$ & $\mathbf{p}$ & Remark \\
& & & $\mathbf{X}$ & & & & & \\
\hline Implementation & Primary & 143 & 82.6364 & 16.36621 & .298 & 0.749 & 0.454 & $>0.05$ \\
& Secondary & 157 & 84.0191 & 15.59400 & & & & \\
\hline
\end{tabular}

Table 3 shows no significant difference in responses of primary and secondary school teachers on the degree of implementation of the language provisions in the NPE $(t=0.749, \mathrm{p}>0.05)$. The hypothesis is therefore retained. Both primary and secondary school teachers responded that the degree of language provisions was low.

5.2.2There is no significant difference in responses of male and female teachers in Southwestern Nigeria on the degree of implementation of the language provisions in the NPE.

Table 4. t-test Showing Difference in Responses of Male and Female Teachers

\begin{tabular}{lllllllll}
\hline Variable & Sex & $\mathbf{N}$ & $\mathbf{Z}$ & $\mathbf{S d}$ & $\mathbf{d f}$ & $\mathbf{t}$ & $\mathbf{p}$ & Remark \\
& & & $\mathbf{X}$ & & & & & \\
\hline Implementation & Male & 109 & 2.4771 & 0.50178 & .298 & 0.424 & 0.672 & $>0.05$ \\
& Female & 191 & 2.5026 & 0.50131 & & & & \\
\hline
\end{tabular}

Table 4 depicts no significant difference in the responses of male and female teachers on implementation of the language provisions in the NPE $(t=0.424, \mathrm{p}>0.05)$. The hypothesis is therefore retained. Both male and female teachers responded that the degree of implementation of language provisions was low.

5.2.3 There is no significant difference in responses of rural and urban school teachers in Southwestern Nigerian on the degree of implementation of the language provisions in the NPE.

Table 5. t-test Showing Difference in Responses of Rural and Urban Teachers

\begin{tabular}{lllllllll}
\hline Variable & SLocation & $\mathbf{N}$ & $\mathbf{Z}$ & sd & df & t & p & Remark \\
& & & $\mathbf{X}$ & & & & & \\
\hline Implementation & Rural & 114 & 82.2982 & 16.35390 & .298 & 0.902 & 0.750 & $>0.05$ \\
& Urban & 186 & 84.0108 & 15.71434 & & & & \\
\hline
\end{tabular}

Table 5 indicates no significant difference in responses of urban and rural teachers on implementation of language provisions in the NPE ( $\mathrm{t}=0.902, \mathrm{p}>0.05)$. The hypothesis is therefore retained. Both urban and rural school teachers responded that the degree of implementation of language provisions was low.

5.2.4 There is no significant difference in responses of public and private school teachers in Southwestern Nigeria on the degree of implementation of the language provisions in the NPE.

Table 6. t-test Showing Difference in Responses of Public and Private School Teachers

\begin{tabular}{lllllllll}
\hline Variable & SType & $\mathbf{N}$ & $\mathbf{Z}$ & sd & df & $\mathbf{t}$ & $\mathbf{p}$ & Remark \\
& & & $\mathbf{X}$ & & & & & \\
\hline Implementation & Public & 189 & 83.8836 & 14.92382 & .298 & 0.741 & 0.368 & $>0.05$ \\
& Private & 111 & 82.4685 & 17.60724 & & & & \\
\hline
\end{tabular}


Table 6, like the others, shows no significant difference in responses of public and private school teachers $(\mathrm{t}=0.741$, $\mathrm{p}>0.05)$. The hypothesis is therefore retained. Both public and private school teachers responded that the degree of implementation of language provisions was low.

5.2.5There is no significant difference in teachers' experience and responses on the degree of implementation of the language provisions in the NPE.

Table 7. Analysis of Teachers' Experience and Responses on the Degree of Implementation of the Language Provisions in the NPE

\begin{tabular}{llllll}
\hline & SS & df & MS & F & Sig. \\
\hline Between Groups & 31.479 & 4 & 7.870 & & \\
Within Groups & 76081.641 & 295 & 257.904 & .031 & .998 \\
Total & 76113.120 & 299 & & & \\
\hline
\end{tabular}

Table 7 shows no significant difference in teachers' experience and responses on the degree of implementation of language provisions in the NPE $(\mathrm{F}=0.031, \mathrm{p}>0.05)$. This implies that both experienced and inexperienced teachers were relatively unanimous in their view that the degree of implementation of the language provisions was low.

\section{Discussion of Findings}

Implementation plays a significant role in realizing the set objectives of the language provisions. The results of the degree of implementation of the language provisions exhibited by this study are very low. Most schools in Southwestern Nigeria do not conform to the language provisions in the NPE. In some schools, Yoruba is introduced as a subject rather than as a medium of instruction from Primaries 1 to 3, while some schools use the English medium from Primaries1 to 6 which continues in the secondary school. This invariably affects learners' acquisition of appropriate skills for language development. Oladipo (2003) asserts that learners who understand the language they are instructed in are more likely to engage meaningfully with content, question what they do not understand and even enjoy the challenge of new things. If the objectives of the language provisions are implemented as indicated in the NPE, the probability is that by the time learners leave the primary school and move to secondary school, they would be able to communicate conveniently in the various indigenous languages and be comfortable in using the English language. However, the reverse is the case, as most learners are neither proficient in the English language nor in the indigenous language.

Carless (1999) opines that teachers are the individuals who implement, adapt, reject or ignore curriculum innovation. Unfortunately, in the observation carried out to ascertain whether teachers actually implement the language provisions in the class when teaching, it was detected that almost all the teachers observed were not implementing the objectives of the language provisions in the NPE. This is in line with Okeke (2002) who opines that the policy is not being adequately implemented in schools due to lack of seriousness on the part of government and school authorities alike. Also Adegoke's (2003) affirmation is in line with the findings of the present study. He claims that the policy provisions on languages to be taught as school subjects are not being implemented in most schools. Furthermore, in this study, the teachers were not aware of the language provisions in the NPE. They taught in any language medium they found suitable during the teaching-learning process. If teachers who interact with learners in the classroom are not conversant with the language provisions, how will they implement them? Any worthwhile language provision requires appropriate strategies for implementation. Therefore, teachers should not only be aware of language provisions (they of course should be involved at the stage of coming up with the policy statements) but should be involved incoming up with strategies for implementation. Nisbet (1974) in Rudd (1982) affirms that if an innovation is to have any hope of being anything more than a passing novelty, then the teachers concerned must be involved from the start. This implies that language teachers in primary and secondary, public and private, rural and urban schools should all be involved at both policy and implementation stages for successful implementation of NPE provisions in Southwestern Nigeria.

\section{Conclusion and Recommendations}

An appraisal of the degree of implementation of the language provisions in primary and secondary schools indicated that the objectives of the language provisions were not adequately implemented in schools. When policy makers do not make their intentions known, the probability is that the teachers may misinterpret their purpose and implement what they like. It could then be said that for the effective implementation of the language provisions, there should be 
a forum where language teachers would be informed of the objectives of language provision in the NPE. Also, implementation strategies and appropriate monitoring measures should be put in place to ensure effectiveness and efficiency. The magnitude and pervasiveness of the low level of implementation of language provisions in primary and secondary schools in Southwestern Nigeria call for very urgent intervention from government. Such a decisive action will create a better learning environment for the development of English Language skills which will translate into better performance of pupils and students in both primary and secondary schools.

\section{References}

Adegoke, K. A. (2003). Relevance of Education: Adapting Curricula and Using African Languages. World Teachers Day Document by Nigeria Union of Teachers.p.11.

Ajibade, Y. A. (1991). The Language Teacher and the National Language Policy. Conference Proceedings of Ife School Curriculum Improvement Group, 102-109.

Ajibade, Y. A. (2001). Language Needs Analysis: A Prerequisite to the Development of a Fundamental Language Education Programme for Nigeria. Ibadan Journal of Educational Studies, 1(1), 25-34.

Babalola, V. O. (2002). Nigeria Languages and the Millennium Development Goals: The Way Forward. The Nigerian Linguists Festschrift Series No.6, 107-114.

Bamgbose, A. (1994). Towards an Implementation of Nigeria's Language Policy on Education. In A. Bamgbose (ed.), Language in Education in Nigeria, Proceeding of the Language Symposium held on 31 October - 4 November, 1977 at the National Language Centre, Federal Ministry of Education, Lagos.

Bamgbose, A. (2003). Intellectualization of African languages: The Nigerian Experience. Workshop on Intellectuaization of African languages, PRAESA, University of Cape Town, 7-12 July 2003.

Barkhuizen, G. P. (2002). Language in Education Policy: Students' Perception of the Status and Role of Xhosa and English. System, 30(4), 499-515. http://dx.doi.org/10.1016/S0346-251X(02)00051-9

Carless, D. (1999). Factors Affecting Classroom Implementation Task-Based Curriculum Renewal in Hong Kong. International Journal of Educational Reform, 8(4), 374-387.

Ehindero, O. J. (2012). Intellectual Foundations of Curriculum Studies. In Press.

Emenanjo, E. N. (1996). Nigerian Language Policy: Perspective and Prospective. JOLAN, 3, 123-134.

Emenanjo, E. N. (1998). Multilingualism, Minority Languages and Language Policy in Nigeria. Agbor: Central Bank, 13.

Emenanjo, E.N. (2004). Nigerian and Foreign Languages in Education: Past, Present and Future Trends' in the Influence of Foreign Languages on the Development of Nigerian Languages. Ondo, (ANLAT), 4-17.

Essien, O. (2003). Language and the Nigerian Reform Agenda. A keynote Address Delivered at the 19th Conference of the Linguistic Association of Nigeria, University of Nigeria, Nsukka, 25th-28th September, Mimeo.

Fafunwa, B. (2005). “Chairman's Opening Remarks”, read at the Presentation of Forms and Functions of English and Indigenous Languages in Nigeria in Honour of Prof. Ayo Banjo's 70th Birthday, University of Ibadan Conference Centre, May 19. Mime.

Federal Government of Nigeria (2004). National Policy on Education (Revised). Lagos: Government Press.

Ikiddeh, I. (2011). English, Bilingualism and a Language Policy for Nigeria. In Unoh, S (ed), Use of English in Communication. Ibadan: Spectrum.

Markee, N. (1997). Managing Curricula Innovation: The Linkage Model. Retrieved from http://www.book.google.com.ng/books

Nancy, H. (2010). Slicing the Onion Ethnographically: Layers and Spaces in Multilingual Language Education Policy and Practice. TESOL Quarterly, 41(3), 509-532.

Nisbet, J. (1974). Curriculum Innovation. A paper presented at Nisbet Frank Late Memorial lecture on Wednesday 3rd July, 1974.

Ogunsiji, A. (2001). Language Attitude and Language Conflict in West Africa. Edited by Herbert Igboanusi, Enicrawunfid Publishers. 
Okeke, V. O. (2002). Linguistic Immersion Scheme within the National Language Policy Implementation Program. Nigerian Journal of Professional Studies in Education, 7, 69.

Oladipo R. (2003). Language Use in the Nigerian Educational System: Problems and Prospects. The Nigerian Linguists Festschrift Series No. 6, $49-59$.

Owu-Ewie, C. (2006). Improving mother tongue education in Ghana at the lower primary level (p1 - p3): A study of schools in ShamaAhanta East Metropolitan Assembly in Ghana. M. A. Thesis: Ohio University.

Phillipson, R. (2003). English in the New World Order: Going Beyond National and Corporate Linguistic Imperialism, Paper Presented at Nigerian Millennium Sociolinguistics Conference, Lagos.

Pressman, J. L., \& Wildavsky, A. (1974). Implementation. USA: University of California Press.

Rudd.A. (1982). Curriculum Development at Local Level. School Council, Curriculum Development Teachers' Group and Centres. Working paper 10(HMSO, London).

Spillane, J. P., Reiser, B. J., \& Reimer, T. (2002). Policy Implementation and cognition: Reframing and Refocusing Implementation Research. Review of Educational Research, 72(3), 387-431. http://dx.doi.org/10.3102/00346543072003387

Tuoyo, M. U. (1999). Inspection and Supervision as practice of Quality Control in the School System. In J.O. Fadipe and E. E. Oluchukwu (eds). Educational Planning and Administration in Nigeria in the 21st Century. Ondo: National Institute for Educational Planning and Administration.

\section{Appendix 1}

\section{Degree of Implementation of Language Provisions Questionnaire (DILPQ)}

This instrument is designed to collect data from teachers, head teachers, principal, students as well as pupils on their responses as regards the degree of implementation of Language provisons in the NPE.

Please supply the necessary information as applicable to you. Any information given will be kept confidential and used only for research purpose.

\section{Section A}

Instruction: Kindly fill in and tick where necessary.

1. Name of school

2. Local Government Area

3. State

4. Rural

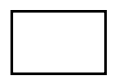

Urban

5. School type: Public

6. Teacher

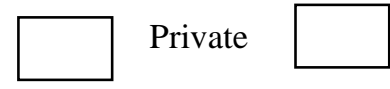

Principal/Head teacherStudent

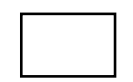

Pupil
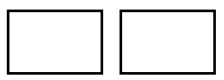

7. Qualification(s)

8. Work experience

9. Subject(s) taught:

10. Sex 


\section{Section B: (For teachers, principals and head teachers)}

Kindly tick as appropriate the option that denotes to what degree you consider the following statements true as regards implementation of language provisions in the National Policy on Education (NPE) in your school.

\begin{tabular}{|c|c|c|c|c|c|c|}
\hline & Statement & $\begin{array}{l}\text { Great } \\
\text { Extent }\end{array}$ & $\begin{array}{l}\text { Some } \\
\text { Extent }\end{array}$ & $\begin{array}{l}\text { Little } \\
\text { Extent }\end{array}$ & Undecided & Not at all \\
\hline 1 & $\begin{array}{l}\text { The syllabi provided for my school reflect language } \\
\text { provisions }\end{array}$ & & & & & \\
\hline 2 & $\begin{array}{l}\text { Students' different learning environments are } \\
\text { considered in teaching English language lessons in my } \\
\text { school }\end{array}$ & & & & & \\
\hline 3 & $\begin{array}{l}\text { Adequate instructional materials are provided by my } \\
\text { school to achieve the language provision objectives }\end{array}$ & & & & & \\
\hline 4 & $\begin{array}{l}\text { Teachers in my school are provided with adequate } \\
\text { information on implementing the language provisions } \\
\text { in the NPE }\end{array}$ & & & & & \\
\hline 5 & $\begin{array}{l}\text { Teachers' population is considered in teaching English } \\
\text { language in my school }\end{array}$ & & & & & \\
\hline 6 & $\begin{array}{l}\text { Students' population is considered in teaching English } \\
\text { language in my school }\end{array}$ & & & & & \\
\hline 7 & $\begin{array}{l}\text { Appropriate avenue is created for teachers to give } \\
\text { feedback on problems confronted as they teach English } \\
\text { language in my school }\end{array}$ & & & & & \\
\hline 8 & $\begin{array}{l}\text { Sufficient awareness is created for teachers to } \\
\text { implement the language provisions in my school }\end{array}$ & & & & & \\
\hline 9 & $\begin{array}{l}\text { Teachers in my school are exposed to proper training } \\
\text { on realizing the objectives of the language provisions }\end{array}$ & & & & & \\
\hline 10 & $\begin{array}{l}\text { Language teachers in my school are ill-equipped for } \\
\text { language provision implementation }\end{array}$ & & & & & \\
\hline 11 & $\begin{array}{l}\text { Learners are influenced by peer group pressure in } \\
\text { language learning in my school }\end{array}$ & & & & & \\
\hline 12 & $\begin{array}{l}\text { I recognize the influence of peer group on language use } \\
\text { (e.g. use of the mother tongue) during English } \\
\text { language lessons in my school }\end{array}$ & & & & & \\
\hline 13 & $\begin{array}{l}\text { I recognize the influence of peer group on language use } \\
\text { (e.g. use of pidgin) during English language lessons in } \\
\text { my school }\end{array}$ & & & & & \\
\hline 14 & $\begin{array}{l}\text { Enforcement officers ensure the implementation of } \\
\text { language provisions in my school }\end{array}$ & & & & & \\
\hline 15 & $\begin{array}{l}\text { The home provides opportunities that help students to } \\
\text { learn language in my school }\end{array}$ & & & & & \\
\hline 16 & $\begin{array}{l}\text { The degree of learners' exposure in the society } \\
\text { influences their learning language in my school }\end{array}$ & & & & & \\
\hline 17 & $\begin{array}{l}\text { Learners' level of proficiency in the mother tongue is } \\
\text { paramount in learning English language in my school }\end{array}$ & & & & & \\
\hline 18 & $\begin{array}{l}\text { Language teachers are adequately posted to schools to } \\
\text { realize the objectives of the language policy in my } \\
\text { school }\end{array}$ & & & & & \\
\hline 19 & $\begin{array}{l}\text { Sufficient fund is provided to meet the demands of } \\
\text { implementing the language provisions in my school }\end{array}$ & & & & & \\
\hline 20 & $\begin{array}{l}\text { English language teachers are competent to implement } \\
\text { the language provisions in the NPE in my school }\end{array}$ & & & & & \\
\hline 21 & $\begin{array}{l}\text { Adequate reading materials are provided in my school } \\
\text { libraries for the realization of the language policy }\end{array}$ & & & & & \\
\hline
\end{tabular}




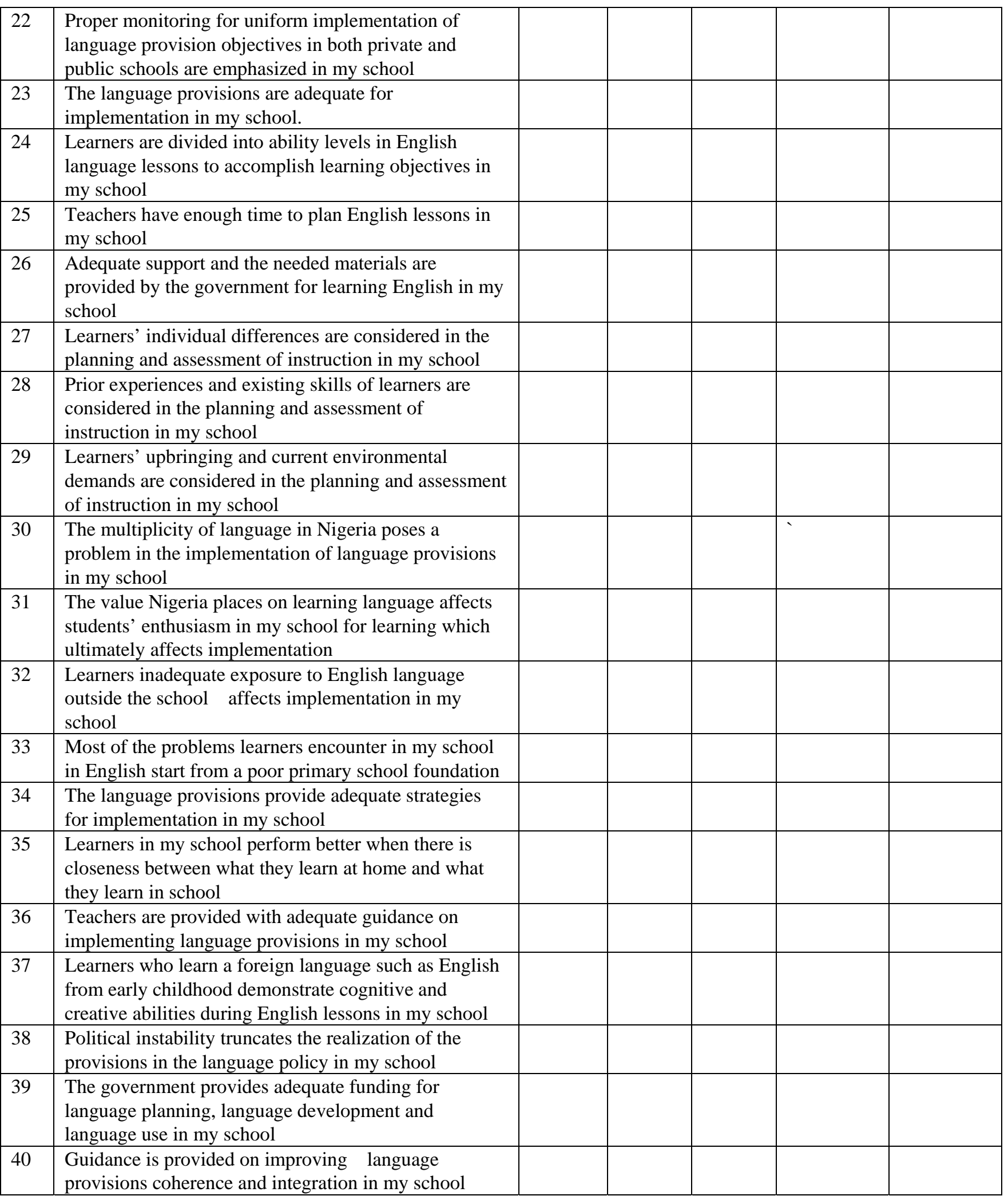




\section{Section C (For Pupils and Students)}

Kindly tick as appropriate the option that indicates to what extent you consider the following statements true as regards the implementation of the language provisions in the National Policy on Education (NPE)

\begin{tabular}{|c|c|c|c|c|}
\hline & Statement & Yes & No & I don't know \\
\hline 1 & My English teacher uses Yoruba to teach & & & \\
\hline 2 & $\begin{array}{l}\text { The school environment promotes my effective learning of } \\
\text { English }\end{array}$ & & & \\
\hline 3 & We are too many for my English teacher to cope with & & & \\
\hline 4 & $\begin{array}{l}\text { My English teacher uses different instructional materials } \\
\text { such as } \\
\begin{array}{ll}\text { (a) computer } & \text { (c) tape recorder } \\
\text { (b) flash cards } & \text { (d) pictures } \\
\text { (e) sentence strips and others }\end{array} \\
\text { (Please tick the ones your teacher uses) }\end{array}$ & & & \\
\hline 5 & $\begin{array}{l}\text { The English lesson is exciting when the teacher uses Yoruba } \\
\text { or the mother tongue to teach me }\end{array}$ & & & \\
\hline 6 & There are few teachers of English language in my school & & & \\
\hline 7 & My teacher uses only textbooks & & & \\
\hline 8 & $\begin{array}{l}\text { My teacher concentrates on the academically good students, } \\
\text { not considering those deficient in English }\end{array}$ & & & \\
\hline 9 & $\begin{array}{l}\text { I contribute to class discussions more in Yoruba than in } \\
\text { English }\end{array}$ & & & \\
\hline 10 & $\begin{array}{l}\text { The way my English teacher teaches does not help me to } \\
\text { communicate well in English }\end{array}$ & & & \\
\hline 11 & I am exposed to English language at home & & & \\
\hline 12 & $\begin{array}{l}\text { The method my teacher employs in teaching English } \\
\text { language is boring }\end{array}$ & & & \\
\hline 13 & $\begin{array}{l}\text { My school library is not well equipped and this reduces our } \\
\text { exposure to English }\end{array}$ & & & \\
\hline 14 & I find it difficult to express myself in English & & & \\
\hline 15 & $\begin{array}{l}\text { I am adequately motivated to read by my English language } \\
\text { teacher }\end{array}$ & & & \\
\hline 16 & $\begin{array}{l}\text { I like to discuss various aspects of English language with my } \\
\text { peer group }\end{array}$ & & & \\
\hline 17 & $\begin{array}{l}\text { My teacher creates a classroom environment in which I can } \\
\text { practice the English language or discuss in the language }\end{array}$ & & & \\
\hline 18 & $\begin{array}{l}\text { My English language teacher moves from what I know to } \\
\text { what I do not know in English }\end{array}$ & & & \\
\hline 19 & $\begin{array}{l}\text { My English language teacher uses different methods to teach } \\
\text { so that I can understand }\end{array}$ & & & \\
\hline 20 & The topics for English lessons are too difficult for me & & & \\
\hline 21 & My teacher gives us tests in English language every week & & & \\
\hline
\end{tabular}




\section{Section D}

\section{Degree of Implementation of Language Provisions Checklist (DILPC)}

This checklist is designed by the researchers for teachers to ascertain whether teachers actually implemented the language provisions in the class as stipulated in the NPE

\begin{tabular}{|c|c|c|c|c|}
\hline & Statement & Fully & Partially & Not at all \\
\hline 1 & $\begin{array}{l}\text { English is included in the curriculum for primary } \\
\text { education in my school }\end{array}$ & & & \\
\hline 2 & $\begin{array}{l}\text { The language of the environment is included in the } \\
\text { curriculum for primary education in my school }\end{array}$ & & & \\
\hline 3 & $\begin{array}{l}\text { English is taught as a subject in the first three years } \\
\text { of primary education in my school }\end{array}$ & & & \\
\hline 4 & $\begin{array}{l}\text { English is used as a medium of instruction in the } \\
\text { first three years of primary school in my school }\end{array}$ & & & \\
\hline 5 & $\begin{array}{l}\text { The language of the environment is the medium of } \\
\text { instruction for the first three years of primary } \\
\text { school in my school }\end{array}$ & & & \\
\hline 6 & $\begin{array}{l}\text { The mother tongue is taught as a subject in the first } \\
\text { three years of primary education in my school }\end{array}$ & & & \\
\hline 7 & $\begin{array}{l}\text { From the fourth year, English is progressively used } \\
\text { as a medium of instruction (i.e. being used together } \\
\text { at the same lesson) in my school }\end{array}$ & & & \\
\hline 8 & $\begin{array}{l}\text { Yoruba is taught as a subject alone from the fourth } \\
\text { year in my school }\end{array}$ & & & \\
\hline 9 & $\begin{array}{l}\text { English is used alone as medium of instruction in } \\
\text { the fourth year in my school }\end{array}$ & & & \\
\hline 10 & $\begin{array}{l}\text { English is a core subject in junior secondary school } \\
\text { in my school }\end{array}$ & & & \\
\hline 11 & $\begin{array}{l}\text { The language of the environment is taught as a } \\
\text { core subject in the junior secondary school in my } \\
\text { school }\end{array}$ & & & \\
\hline 12 & $\begin{array}{l}\text { English is taught as a subject in the senior } \\
\text { secondary school in my school }\end{array}$ & & & \\
\hline 13 & $\begin{array}{l}\text { A major Nigerian language is taught as a core } \\
\text { subject in the senior secondary school in my school }\end{array}$ & & & \\
\hline
\end{tabular}

